Eur. J. Clin. Chem. Clin. Biochem.

Vol. 30, 1992, pp. 717-727

(C) 1992 Walter de Gruyter \& Co.

Berlin $\cdot$ New York

\title{
Improved Detection of Hepatitis C Virus RNA by Reverse Transcription and Polymerase Chain Reaction
}

\author{
By C. Wolff, Kathrin Schlüter, W. Prohaska and K. Kleesiek \\ Herzzentrum Nordrhein-Westfalen, Universitätsklinik der Ruhr-Universität Bochum, Institut für Laboratoriums- \\ und Transfusionsmedizin, Bad Oeynhausen
}

(Received April 8/July 20, 1992)

\begin{abstract}
Summary: The polymerase chain reaction with prior reverse transcription of RNA into cDNA was applied to hepatitis $\mathrm{C}$ virus RNA detection in human serum samples of different origin. In order to eliminate false negative results, the following steps were optimized: RNA extraction, reverse transcription, and oligonucleotide primer selection.
\end{abstract}

We compared different RNA extraction methods using guanidinium salt/detergent and proteinase K digestion/ phenol extraction, and tested virus particle enrichment with polyethylene glycol precipitation and ultracentrifugation. RNA extraction with guanidinium salt/detergent was the most efficient method.

Ultracentrifugation of single samples did not improve hepatitis C virus RNA detection. Polyethylene glycol precipitation performed poorly.

Recombinant thermostable reverse transcriptase produced cDNA from fewer samples than did Moloney murine leukaemia virus reverse transcriptase.

Nested oligonucleotide primers from the $5^{\prime}$-terminal non-coding region of the hepatitis $\mathrm{C}$ virus genome amplified cDNA from more samples than did primers from the coding regions. Thirty six anti-hepatitis $\mathrm{C}$ virus antibody positive samples were tested; nested primers (nucleotides 6 to 327 and 15 to 288) yielded 21 amplificates, whereas primers from the coding region produced 16 amplificates (nucleotides $4684-5276$ ) and 5 amplificates (nucleotides 5166-5270), respectively.

The most efficient combination of steps was RNA extraction with guanidinium salt solution, reverse transcription with Moloney murine leukaemia virus reverse transcriptase and nested polymerase chain reaction primed with primers from the $5^{\prime}$-terminal non-coding region of the hepatitis $\mathrm{C}$ virus genome. Other combinations produced more false negative results.

Three different groups of anti-hepatitis $\mathrm{C}$ virus antibody positive individuals had markedly different viraemia patterns: Hepatitis C virus RNA was detected in the sera of only $10 \%$ of anti-hepatitis $C$ virus antibody positive blood donors, but in $90 \%$ of anti-hepatitis $\mathrm{C}$ virus antibody positive patients with clinically manifest hepatitis $\mathrm{C}$, and $90 \%$ of anti-hepatitis $\mathrm{C}$ virus antibody positive haemophiliacs who had received plasma products in the past which had not been virus-inactivated. No hepatitis $\mathrm{C}$ virus RNA could be detected in the sera of 450 anti-hepatitis $C$ virus antibody negative blood donors with elevated serum alanine aminotransferase catalytic concentrations.

\section{Introduction}

The hepatitis $\mathrm{C}$ virus, a single stranded RNA virus with some structural relations to the flavivirus family, has been identified as the infectious agent responsible for the major part of "hepatitis non-A, non-B" infections $(1-5)$. Its nucleic acid sequence was determined from cDNA clones derived from the nucleic acid extracts of the plasma of an experimentally infected 
chimpanzee (1). The natural modes of hepatitis $C$ virus transmission are not yet completely understood $(3,6)$. Since the introduction of the hepatitis B surface antigen assay to blood donor screening in 1972, however, it has been known that blood transfusions and parenterally administered human blood products (e. g. coagulation factors, or fresh frozen plasma) constitute a major route of "hepatitis non-A, non-B" transmission (7).

The nucleic acid sequences of the first hepatitis $C$ virus cDNA clones provided the basis for the construction of recombinant peptides representing putative hepatitis $C$ virus proteins $(4,8)$. Cloned hepatitis $\mathrm{C}$ virus peptides were employed in anti-hepatitis $\mathrm{C}$ virus enzyme immunoassays. Since 1989, such enzyme immunoassays have identified many clinical cases of "hepatitis non- $A$, non- $B$ " as hepatitis $C$ virus infections $(4,9,10,11)$. Anti-hepatitis $C$ virus antibody screening of blood using these enzyme immunoassays, helped to identify and sort out apparently healthy blood donors with anti-hepatitis $\mathrm{C}$ virus antibodies who otherwise might have transmitted the virus (11).

At present, hepatitis $C$ virus cannot be detected by cell culture techniques. Neither can the virus be demonstrated with certainty by electron microscopy. This may be due to the comparatively low particle numbers of the virus $\left(100-1000 \times 10^{3} / 1\right)$ in viraemic samples $(12,13)$. For the same reason, other methods for the detection of specific nucleic acid sequences, such as dot blot hybridization (14) or luminescence-labelled direct hybridization (15) are not applicable to hepatitis $\mathrm{C}$ virus detection.

The polymerase chain reaction with prior reverse transcription of viral RNA into cDNA is at present the only method applicable to hepatitis $C$ virus detection. The general potential of this method became evident very soon after the discovery of the hepatitis $C$ virus, but rather different results were obtained with different primers and different RNA extraction methods $(12,16-23)$. Such divergent results of hepatitis $C$ virus RNA detection are in part due to the fact that the various isolates of hepatitis $C$ virus exhibit rather low RNA sequence homologies for the major part of the genome $(1,8,24-29,45)$. However, the 5'-terminal non-coding region is highly conserved $(21,30$, 31,32 ), thus providing a good target for the polymerase chain reaction. We compared oligonucleotide primers targeted at different sections of the genome, including the highly conserved 5 -terminal non-coding region $(12,17,20)$.

The method was optimized for the monitoring of patients and blood donors.

\section{Materials and Methods}

Sera

Five hundred thirty three (533) sera were assayed. They were obtained from

1. Blood donors $(n=486)$

1.1. Anti-hepatitis $\mathrm{C}$ virus antibody negative blood donors with elevated serum alanine aminotransferase (above 25 $\mathrm{U} / \mathrm{l})(\mathrm{n}=450)$,

1.2. Apparently healthy anti-hepatitis $C$ virus antibody positive, anti-HBc negative blood donors with serum alanine aminotransferase below $25 \mathrm{U} / \mathrm{l}(\mathrm{n}=36)$,

2. Haemophiliacs $(\mathrm{n}=22)$

2.1. Anti-hepatitis $\mathrm{C}$ virus antibody positive haemophiliacs who had received multiple doses of plasma-derived clotting factors before the introduction of plasma inactivation procedures $(\mathrm{n}=19)$,

2.2. Anti-hepatitis $\mathrm{C}$ virus antibody negative juvenile haemophiliacs who had exclusively received virus inactivated human plasma products $(\mathrm{n}=3)$,

3. Anti-hepatitis $C$ virus antibody positive patients with hepatitis non-A, non-B $(\mathrm{n}=30)$,

3.1. Patients with acute hepatitis non- $A$, non-B $(n=6)$,

3.2. Patients with chronic hepatitis non A, non-B (22),

3.3. Cardiac surgery patients whose anti-hepatitis $C$ virus antibodies had been discovered by pre-operative serological screening $(\mathrm{n}=2)$.

The sera were stored at $-20^{\circ} \mathrm{C}$.

\section{RNA preparation}

The whole extraction process was performed in $1.5 \mathrm{ml}$ plastic tubes (Eppendorf, Hamburg), and centrifugations were performed at $10500 \mathrm{~g}$ and $6^{\circ} \mathrm{C}$, unless stated otherwise.

\section{Guanidinium salt extraction}

Serum $(200 \mu \mathrm{l})$ was mixed with $600 \mu \mathrm{l} 4 \mathrm{~mol} / \mathrm{l}$ guanidinium isothiocyanate, $25 \mathrm{mmol} / 1$ sodium citrate $\mathrm{pH} 7.0,5 \mathrm{~g} / 1 \mathrm{~N}$-lauroylsarcosine, $0.1 \mathrm{~mol} / 1$ mercaptoethanol in $1.5 \mathrm{ml}$ tubes at room temperature by brief vortexing. Phenol equilibrated with $1 \mathrm{~mol} / \mathrm{l}$ Tris-Cl, $\mathrm{pH} 7.5(600 \mu \mathrm{l})$ was added and the tubes were vortexed. A solution of baker's yeast RNA (type III, Sigma, Taufkirchen) $(1.2 \mathrm{~g} / 1,2 \mu \mathrm{l})$ was added and mixed, followed by $100 \mu \mathrm{l}$ chloroform. The tubes were briefly vortexed again, placed on ice for 15 minutes and centrifuged for 15 minutes. The upper aqueous phases (ca $750 \mu \mathrm{l}$ ) were transferred to new tubes and extracted with an equal volume of chloroform. The interphases, containing proteinaceous material, were completely left behind. The mixtures were again centrifuged as before, and the aqueous layers without interphases were transferred to new tubes and mixed with at least an equal volume (or up to two volumes) of ice cold isopropanol. The tubes were left overnight at $-20^{\circ} \mathrm{C}$, then centrifuged for 20 minutes. The supernatants were carefully poured off.

The pellets were washed with $200 \mu$ l of aqueous ethanol, volume fraction 0.7 . After decantation, the tubes were left open for 60 min at $40{ }^{\circ} \mathrm{C}$ in order to dry out before the pellets were redissolved in $10 \mu \mathrm{l}$ aqua ad iniectabilia (RNase free). The solutions were frozen at $-20^{\circ} \mathrm{C}$ for storage or used directly for reverse transcription (modified according to 1.c. (12) and (33). 


\section{Proteinase $\mathrm{K}$ digestion}

Serum $(50 \mu \mathrm{l})$ was diluted with $150 \mu \mathrm{l}$ aqua ad iniectabilia and $200 \mu \mathrm{l}$ lysis buffer, containing $0.2 \mathrm{~mol} / 1$ Tris- $\mathrm{Cl} \mathrm{pH} \mathrm{7.5,} 25$ $\mathrm{mmol} / 1 \mathrm{EDTA}, 0.3 \mathrm{~mol} / 1 \mathrm{NaCl}$ and $20 \mathrm{~g} / \mathrm{l} \mathrm{SDS}$. A stock solution $(2 \mu \mathrm{l})$ containing $20 \mathrm{~g} / \mathrm{l}$ Proteinase $\mathrm{K}$ (Merck, Darmstadt) was added, and the mixtures were incubated for 90 minutes at $37^{\circ} \mathrm{C}$, followed by two extractions, each with $400 \mu$ phenol (equilibrated with $1 \mathrm{~mol} / \mathrm{l}$ Tris-Cl, $\mathrm{pH}$ 7.5)/chloroform/isoamyl alcohol $(25 / 24 / 1$ by vol.), then one extraction with $300 \mu$ l chloroform. After each extraction the aqueous phases were transferred to new tubes, and the interphases, containing proteinaceous material, were completely left behind. To the final aqueous phases $1 \mu \mathrm{l}$ of a stock solution of glycogen (from mussels, 20 $\mathrm{g} / \mathrm{l}$, Boehringer, Mannheim) and then $900 \mu \mathrm{l}$ of ice cold ethanol were added, and the tubes were left overnight at $-20^{\circ} \mathrm{C}$. The precipitates were collected by centrifugation for 20 minutes. The pellets were vortexed in $200 \mu \mathrm{l}$ pure ethanol, re-centrifuged for 20 minutes and dried at $40^{\circ} \mathrm{C}$ after decantation of the supernatants. The dried pellets were dissolved in $10 \mu \mathrm{l}$ aqua ad iniectabilia and either used directly for reverse transcription or stored at $-20{ }^{\circ} \mathrm{C}$ (modified acc. to 1.c. (19)).

\section{Polyethylene glycol precipitation}

Serum $(500 \mu \mathrm{l})$ diluted with $500 \mu \mathrm{l}$ aqua ad iniectabilia, and $500 \mu \mathrm{l} 300 \mathrm{~g} / \mathrm{l}$ polyethylene glycol, average $M_{\mathrm{r}} 8000$ (Serva, Heidelberg), in $0.1 \mathrm{~mol} / 1 \mathrm{NaCl}$ were added. After brief vortexing, the tubes were placed on ice for 60 minutes before centrifugation for 15 minutes. The supernatants were completely removed by aspiration, and the pellets dissolved in $300 \mu \mathrm{l}$ Tris/ EDTA buffer (10 mmol/1 Tris-Cl pH 7.0, $1 \mathrm{mmol} / 1$ EDTA). Following the addition of $40 \mu \mathrm{l} 100 \mathrm{~g} / \mathrm{l} \mathrm{SDS}$, the mixtures were extracted with $300 \mu \mathrm{l}$ phenol (equilibrated with $1 \mathrm{~mol} / 1$ Tris-Cl $\mathrm{pH}$ 7.5), then centrifuged for $10 \mathrm{~min}$. The aqueous phases were transferred to new tubes and extracted with $300 \mu \mathrm{l}$ chloroform. After 5 minutes centrifugation, the aqueous phases were transferred to tubes prefilled with $30 \mu \mathrm{l} 3 \mathrm{~mol} / \mathrm{l}$ sodium acetate, $\mathrm{pH}$ 5.0. Glycogen stock solution (from mussels, $20 \mathrm{~g} / \mathrm{l}$, Boehringer, Mannheim) $(1 \mu \mathrm{l})$ was added and the tubes were vortexed. Ice cold ethanol $(1 \mathrm{ml})$ was added, the tubes were briefly vortexed again and left overnight at $-65^{\circ} \mathrm{C}$. After centrifugation for 20 minutes, the supernatants were completely removed and the tubes were left open at room temperature for two minutes to allow the remaining ethanol to evaporate. The pellets were dissolved in $10 \mu \mathrm{l}$ aqua ad iniectabilia and used directly or stored frozen at $-20^{\circ} \mathrm{C}$ (modified acc. to 1.c. (18)).

\section{Ultracentrifugation}

Concentration of samples: $3.5 \mathrm{ml}$ serum were diluted with 31.5 $\mathrm{ml}$ of autoclaved $0.2 \mathrm{~mol} / \mathrm{l}$ phosphate buffered saline, $\mathrm{pH} 7.5$, and centrifuged for 3 hours at $100000 \mathrm{~g}, 4^{\circ} \mathrm{C}$ (Kontron T-2070 centrifuge, TFT 7038 rotor, $35000 \mathrm{~min}^{-1}$ ). The pellet was dissolved in $650 \mu \mathrm{l}$ guanidinium isothiocyanate solution and immediately processed as described above.

Simulated concentration from pooled samples: three $200 \mu \mathrm{l}$ serum samples known to contain hepatitis $C$ virus were mixed each with $3.8 \mathrm{ml}$ serum from healthy blood donors and $31 \mathrm{ml}$ phosphate-buffered saline. A $200 \mu \mathrm{l}$ sample was taken from each of these dilutions. After centrifugation, $200 \mu$ l samples drawn from the upper and the lower zone of the supernatants, and the pellets were all extracted with guanidinium salt solution as described above. The RNA extracts were dissolved in $10 \mu \mathrm{l}$ aqua ad iniectabilia. Samples $(2 \mu 1)$ of the RNA extracts were used to make dilution series $\left(10^{0}, 10^{1}, 10^{2}, 10^{3}, 10^{4}\right.$-fold). All dilution RNA solutions were subjected to reverse transcription with Moloney murine leukaemia virus reverse transcriptase and nested polymerase chain reaction with primers NCR 1 - NCR 4 (17).

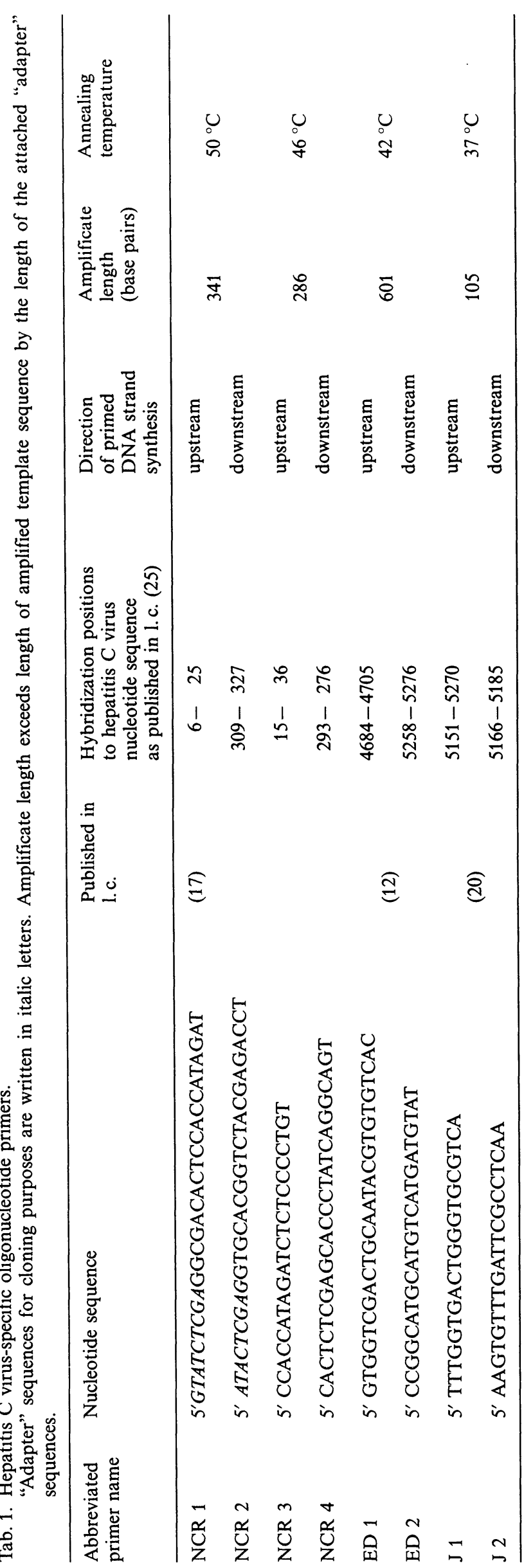




\section{Reverse transcription}

RNA extract $(2 \mu \mathrm{l})$ was used for reverse transcription with 20 units of Moloney murine leukaemia virus reverse transcriptase (Pharmacia, Freiburg) and 20 units of RNAse inhibitor from human placenta (RNA Guard, pharmacia), in $20 \mu$ l reactions containing $5 \mathrm{mmol} / \mathrm{l} \mathrm{HEPES}, 50 \mathrm{mmol} / \mathrm{l}$ Tris- $\mathrm{Cl} \mathrm{pH} \mathrm{7.5,} 73$ $\mathrm{mmol} / 1 \mathrm{KCl}, 3 \mathrm{mmol} / 1 \mathrm{MgCl}_{2}, 10 \mathrm{mmol} / \mathrm{l}$ 1,4-dithiothreitol, and $0.5 \mathrm{mmol} / 1$ of each 2 -deoxynucleoside triphosphate. The concentration of the downstream primer (either NCR 2 or ED 2) was $1 \mu \mathrm{mol} / \mathrm{l}$. The reaction mixtures were overlaid with a drop of liquid paraffin (DAB 9) and left at $37^{\circ} \mathrm{C}$ for 90 minutes, then heated to $95^{\circ} \mathrm{C}$ for 5 minutes and chilled on ice for 2 minutes before further processing or storage at $-20^{\circ} \mathrm{C}$.

Alternatively, recombinant reverse transcriptase from Thermus aquaticus ("thermostable reverse transcriptase", Perkin Elmer Cetus), an enzyme with both reverse transcriptase and DNA polymerase activities, was used for reverse transcription and the subsequent polymerase chain reaction according to the manufacturer's protocol: $2 \mu \mathrm{l}$ aqueous solution of extracted RNA were made up to a total volume fo $20 \mu$, containing 1.0 $\mathrm{mmol} / \mathrm{l} \mathrm{MnCl}$, $10 \mathrm{mmol} / \mathrm{l}$ Tris-Cl pH 8.3, $90 \mathrm{mmol} / 1 \mathrm{KCl}, 200$ $\mu \mathrm{mol} / \mathrm{l}$ of each 2 -deoxynucleoside triphosphate, $0.75 \mu \mathrm{mol} / \mathrm{l}$ downstream primer (NCR 2 or ED 2) and 5 units of thermostable reverse transcriptase. The mixtures were overlaid with paraffin and incubated at $70^{\circ} \mathrm{C}$ for 10 minutes. Then the total volume was increased to $100 \mu$ l by addition of $8 \mu \mathrm{l}$ "chelating buffer" (containing glycerol, volume fraction $0.5,100 \mathrm{mmol} / \mathrm{l}$ Tris-Cl pH $8.3,1 \mathrm{~mol} / 1 \mathrm{KCl}, 7.5 \mathrm{mmol} / 1 \mathrm{EGTA}$ and $5,0 \mathrm{~g} / \mathrm{l}$ Tween 20), $10 \mu \mathrm{l} 25 \mathrm{mmol} / 1 \mathrm{MgCl}_{2}, 1 \mu \mathrm{l} 20 \mu \mathrm{mol} / \mathrm{l}$ upstream primer (NCR 1 or ED 1), and $61 \mu \mathrm{l}$ water, and the polymerase chain reaction was started.

\section{Oligonucleotide primers}

Syntheses were performed using phosphite technology on an automated synthesizer (Applied Biosystems, Pfungstadt). After cleavage of the protecting groups, the oligonucleotides were purified by gel electrophoresis on $18 \%$ polyacrylamide gels (34). Properties of the oligonucleotides are listed in table 1.

\section{Polymerase chain reaction}

A $5 \mu$ fraction of a completed Moloney murine leukaemia virus reverse transcriptase reaction mixture was transferred to a 0.75 $\mathrm{ml}$ thermocycler tube, using stuffed pipette tips to prevent carryover via aerosols. The total polymerase chain reaction mix was $50 \mu \mathrm{l}$, containing $50 \mathrm{mmol} / 1 \mathrm{KCl}, 20 \mathrm{mmol} / \mathrm{l}$ Tris- $\mathrm{Cl} \mathrm{pH}$ $8.4,1.5 \mathrm{mmol} / 1 \mathrm{MgCl}_{2}, 0.1 \mathrm{~g} / \mathrm{l}$ gelatin, $200 \mu \mathrm{mol} / \mathrm{l}$ of each $2^{\prime}-$ deoxynucleoside-5'-triphosphate, $0.4 \mu \mathrm{mol} / \mathrm{l}$ of both oligonucleotide primers and 2 units of Thermus aquaticus DNA polymerase (Perkin Elmer). When a single set of primers was used, 35 thermal cycles were performed. For the "nested" polymerase chain reaction, 35 cycles were performed, and an aliquot of the reaction mix was then transferred to new tubes for further amplification in another 30 thermal cycles. In order to prevent "amplificate carryover", we followed the guidelines given by Kwok (35). The work was divided into three activities: Pre amplification, amplification, and post amplification; a separate room was reserved for each.

In order to exclude false positive results, parallel polymerase chain reactions were performed using cDNA and untranscribed RNA extracts. For negative controls we used the complete polymerase chain reaction mixes run in the same series of amplifications, but without cDNA; for positive controls we used cDNA samples obtained by reverse transcription of guanidinium salt RNA extracts of the serum of a viraemic hepatitis C patient.

\section{Nested polymerase chain reaction}

The incubation mixture of the first amplification reaction $(1 \mu \mathrm{l})$ was transferred with a disposable glass capillary pipette (SüdLaborbedarf, Gauting) into a thermocycler tube containing $24 \mu \mathrm{l}$ polymerase chain reaction mix as described for the first amplification, but with "nested" primers NCR 3 and NCR 4 instead of "outer" primers NCR 1 and NCR 2, or with J 1 and J 2 instead of ED 1 and ED 2. 30 thermal cycles were performed.

\section{Temperature cycle conditions}

1 minute $94^{\circ} \mathrm{C}, 1$ minute annealing temperature (see tab. 1), 1 minute $72{ }^{\circ} \mathrm{C}$. In order to reduce the time intervals required for temperature adjustment, a thermocycler equipped with high capacity Peltier elements was used (Landgraf, Hannover). Typical heating and cooling rates were $2.7-2.9^{\circ} \mathrm{C} / \mathrm{s}$, permitting completion of 30 temperature cycles in 115 minutes.

\section{Monitoring of amplificate carryover}

Swab controls of all places involved in work with polymerase chain reaction were taken every two weeks by excessive scratching of the control area with plastic pipettes. The pipette tips were then cut off with single-use razor blades, placed in thermocycler tubes containing reaction mix for the polymerase chain reaction, and the nested polymerase chain reaction was performed with nested primers NCR 1-NCR 4. Possible aerosol transfer of amplificates was monitored by placing open tubes on ice, containing a complete reaction mix for the polymerase chain reaction, for periods of up to four hours in many parts of the laboratory, and subsequent performance of the polymerase chain reaction. RNA extracts were subjected to the polymerase chain reaction in parallel with the samples which had been reverse transcribed into cDNA.

\section{Amplificate analysis}

Samples $(8 \mu \mathrm{l})$, either from a $25 \mu \mathrm{l}$ "nested" polymerase chain reaction, from a $100 \mu \mathrm{l}$ polymerase chain reaction with thermostable reverse transcriptase, or from a $50 \mu$ l polymerase chain reaction with a single set of primers, were mixed with $3 \mu \mathrm{l} 300$ $\mathrm{g} / \mathrm{l}$ sucrose, $1 \mathrm{~g} / \mathrm{l}$ bromphenol blue, $1 \mathrm{~g} / \mathrm{l}$ xylene cyanol in 450 $\mathrm{mmol} / 1$ Tris borate, $\mathrm{pH} 8.3,10 \mathrm{mmol} / \mathrm{l}$ EDTA, loaded onto agarose gels ( $3 \mathrm{~g} / 1$ agarose, $3: 1 \mathrm{NuSieve,} \mathrm{FMC} \mathrm{BioProducts)}$ and run for 1 hour at $5 \mathrm{~V} / \mathrm{cm}$ in Tris/borate/EDTA buffer ( 90 $\mathrm{mmol} / \mathrm{l}$ Tris borate, $\mathrm{pH} 8.3,2 \mathrm{mmol} / \mathrm{l}$ EDTA) in parallel with molecular mass markers (Boehringer DNA markers $\mathrm{V}$ with $8-587$ nucleotides and VIII with 19-1114 nucleotides). The gels were stained at room temperature for 45 minutes in Tris/ borate/EDTA buffer containing $1 \mathrm{mg} / \mathrm{l}$ ethidium bromide and photographed on a $312 \mathrm{~nm}$ transilluminator $\left(8000 \mu \mathrm{W} / \mathrm{cm}^{2}\right.$, Renner, Pfungstadt) under a fume hood.

\section{Sequence determination of amplificates}

Slices containing ethidium bromide-stained amplificates were excised from agarose electrophoresis gels, and the amplificates were purified by absorption to silica with "spin bind" sintered glass centrifuge columns (FMC Bioproducts, distributed by Biozym, Hameln) according to the manufacturer's protocol. The purified material was blunt-end ligated into M 13 plasmids, cloned, and sequenced according to 1.c. (36), using $2^{\prime}$-deoxycytidine $\alpha-\left[{ }^{35} \mathrm{~S}\right]$ thiophosphate as a label.

\section{Anti-hepatitis C virus antibody detection}

Anti-hepatitis $\mathrm{C}$ virus antibody screening was performed with a "2nd generation" enzyme immunoassay employing a combination of recombinant hepatitis $\mathrm{C}$ virus peptides (Abbott, Wies- 
baden) (11). Positive test results were confirmed by parallel testing with two supplementary enzyme immunoassays employing structural and non-structural hepatitis $C$ virus antigens, respectively (Abbott, Wiesbaden). When both supplementary assays were negative, the anti hepatitis $C$ virus antibody status was defined as negative, and the positive reaction in the screening assay was assumed to be false positive.

Determination of serum alanine aminotransferase activity

The optimized standard method of the German Society of Clinical Chemistry was used (37).

\section{Results}

Comparison of different primer pairs (tab. 2)

Thirty six anti hepatitis $C$ virus antibody positive sera (22 from hepatitis $\mathrm{C}$ patients, 14 from blood donors) were extracted by the guanidinium salt method, and RNA was reverse transcribed with Moloney murine leukaemia virus reverse transcriptase. Hepatitis $\mathrm{C}$ virus RNA was detected in 21 of these sera (all from hepatitis $\mathrm{C}$ patients). Nested polymerase chain reaction with primers NCR 1 - NCR 4 detected hepatitis $C$ virus RNA in all of these 21 sera, the primer pair NCR 1/NCR 2 alone detected RNA in 19 of the sera, the primer pair ED 1/ED 2 in 16 sera, and nested polymerase chain reaction with ED 1/ED 2 and J 1/ $\mathrm{J} 2$ in only 5 sera. The latter finding is due to the fact that primers $\mathrm{J} 1 / \mathrm{J} 2$ were originally designed for detection of the Japanese strain of hepatitis $C$ virus, not the European/American strains. They do not perfectly match the amplificate obtained with the primer pair ED $1 /$ ED 2.

\section{Efficiency of different RNA extraction methods (tab. 3)}

Twenty two anti-hepatitis $C$ virus antibody positive sera (13 from blood donors, 9 from hepatitis $C$ patients) were extracted using three different methods (guanidinium salt, proteinase $\mathrm{K}$, and polyethylene glycol precipitation). Ultracentrifugation prior to RNA extraction was performed in parallel.

Tab. 2. Comparison of different pairs of oligonucleotide primers.

Sequences of the oligonucleotide primers and their relative positions in the hepatitis $C$ virus genome are listed in table 1. + : amplificate of expected size detected by ethidium fluorescence after polymerase chain reaction.

-: no amplificate detected

Oligonucleotide primers: NCR 1 -NCR 4 from the $5^{\prime}$-terminal non-coding region, ED 1/ED 2 and J $1 / \mathrm{J} 2$ from the coding region of the hepatitis $C$ virus genome.

Samples $1-22$ were from anti-hepatitis $C$ virus antibody positive hepatitis $C$ patients, samples $23-36$ were from antihepatitis $\mathrm{C}$ virus antibody-positive blood donors.

\begin{tabular}{|c|c|c|c|c|}
\hline \multirow[t]{2}{*}{ Sample number } & \multicolumn{4}{|c|}{ Oligonucleotide primers } \\
\hline & $\begin{array}{l}\text { NCR } 1 / \text { NCR } 2 \\
\text { (35 cycles) }\end{array}$ & $\begin{array}{l}\text { NCR } 1 / \text { NCR } 2 \\
(35 \text { cycles) } \\
\text { and nested } \\
\text { NCR } 3 / \text { NCR } 4 \\
\text { (30 cycles) }\end{array}$ & $\begin{array}{l}\text { ED 1/ED } 2 \\
\text { (35 cycles) }\end{array}$ & $\begin{array}{l}\text { ED 1/ED } 2 \\
\text { ( } 35 \text { cycles) } \\
\text { and nested } \\
\mathrm{J} 1 / \mathrm{J} 2 \\
\text { ( } 30 \text { cycles) }\end{array}$ \\
\hline 1 & + & + & + & + \\
\hline 2 & + & + & + & + \\
\hline 3 & + & + & + & + \\
\hline 4 & + & + & + & - \\
\hline 5 & + & + & + & - \\
\hline 6 & + & + & + & - \\
\hline 7 & + & + & + & - \\
\hline 8 & + & + & + & - \\
\hline 9 & + & + & + & - \\
\hline 10 & + & + & + & - \\
\hline 11 & + & + & + & - \\
\hline 12 & + & + & + & - \\
\hline 13 & + & + & + & - \\
\hline 14 & + & + & + & - \\
\hline 15 & + & + & + & - \\
\hline 16 & + & + & - & - \\
\hline 17 & + & + & - & - \\
\hline 18 & + & + & - & - \\
\hline 19 & + & + & - & - \\
\hline 20 & - & + & + & + \\
\hline 21 & - & & - & + \\
\hline $22-36$ & all - & all - & all - & all - \\
\hline 36 sera & 19 positive & 21 positive & 16 positive & 5 positiv \\
\hline
\end{tabular}




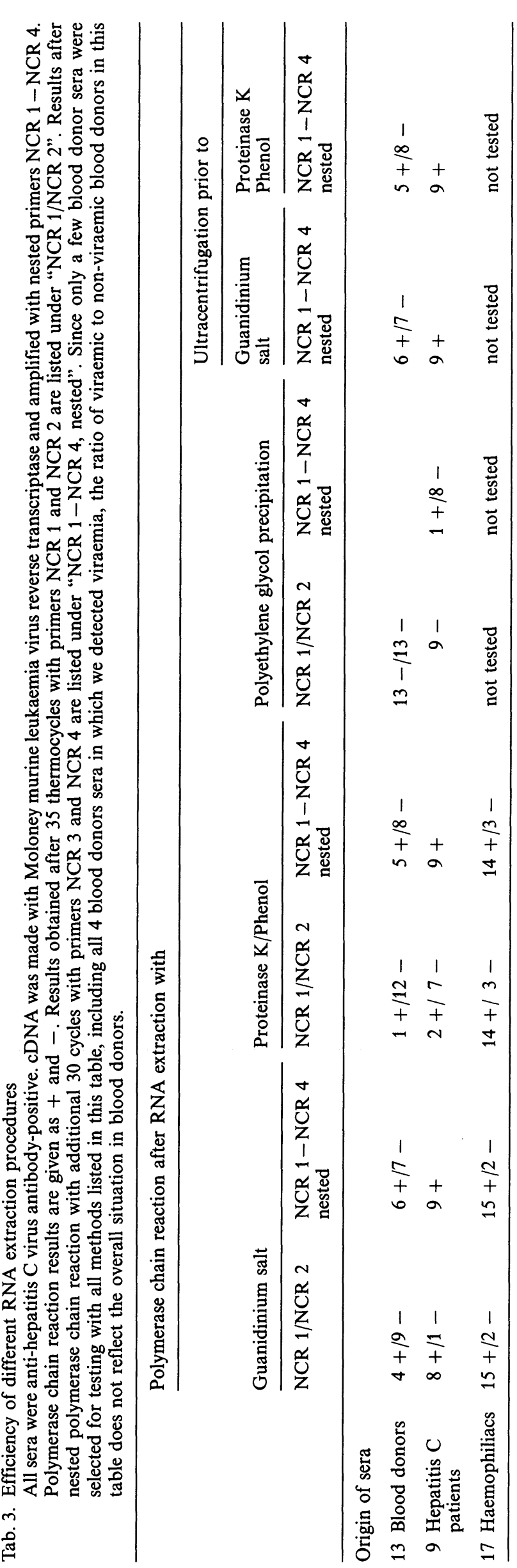

Seventeen anti-hepatitis $\mathrm{C}$ virus antibody-positive sera from haemophiliacs were extracted both with guanidinium salt and proteinase $\mathrm{K} /$ phenol. Extraction with guanidinium salt solution gave the best overall yield. Polyethylene glycol precipitation performed poorly.

Ultracentrifugation of large serum samples did not improve the overall performance of RNA extraction. The same pattern of positive and negative polymerase chain reaction results was obtained after direct extraction of $200 \mu \mathrm{l}$ serum and after prior concentration of the virus particles from $3.5 \mathrm{ml}$ serum by ultracentrifugation.

When the overnight alcohol precipitation step of RNA was shortened, the resulting material was of poor quality, resulting in co-amplification of many artefacts along with the desired amplificates. As judged from the amplificate electrophoresis patterns, the parallel extraction with one method of serum, citrate plasma and EDTA plasma from the same patient led to identical results (8 patients tested).

Three frozen sera from viraemic patients with chronic hepatitis $C$, which served as positive controls, were thawed on ten occasions in order to remove small samples for RNA extraction. Hepatitis C virus RNA was consistently detected in these samples by the combination: guanidinium salt extraction/reverse transcription/ nested polymerase chain reaction with primers NCR 1 - NCR 4.

Reverse transcription with two different enzymes (tab. 4)

Sixteen anti-hepatitis $C$ virus antibody-positive sera (7 from blood donors and 9 from hepatitis $C$ patients) were extracted with guanidinium salt solution, then reverse transcribed in parallel with Moloney murine leukaemia virus reverse transcriptase and with recombinant thermostable reverse transcriptase derived from Thermus aquaticus (Perkin Elmer). Among the 7 blood donor sera used in this investigation, we included deliberately 4 sera in which hepatitis $C$ virus RNA had previously been detected, so that the efficiency of the reverse transcriptases would be tested with sera of low viraemia. From 13 sera, including the 4 blood donor sera, cDNA was obtained with Moloney murine leukaemia virus reverse transcriptase, whereas recombinant thermostable reverse transcriptase yielded cDNA from only 7 patient sera and from no blood donor sera. cDNA was amplified by nested polymerase chain reaction with primers NCR 1 - NCR 4. 
Tab. 4. Comparison of two reverse transcriptases

Sixteen anti-hepatitis $\mathrm{C}$ virus antibody positive sera were used. Nested polymerase chain reaction with cDNA was performed with oligonucleotide primers NCR 1-NCR 4; assays with cDNA from thermostable reverse transcriptase were performed in duplicate.

+ : Amplificate detected with ethidium bromide stain

-: No amplificate detected.

Guanidinium extract: $\quad$ Sera extracted with guanidinium salt/detergent

Proteinase K extract: $\quad$ Sera extracted with proteinase $\mathrm{K} / \mathrm{phenol}$

\begin{tabular}{lll}
\hline Origin of samples & $\begin{array}{l}\text { Moloney murine leukaemia } \\
\text { virus reverse transcriptase }\end{array}$ & $\begin{array}{l}\text { Recombinant reverse } \\
\text { transcriptase from } \\
\text { Thermus aquaticus }\end{array}$ \\
\hline $\begin{array}{l}\text { Blood donors }(\mathrm{n}=7) \\
\text { (Guanidinium extract) }\end{array}$ & $4+/ 3-$ & $7-$ \\
$\begin{array}{l}\text { Hepatitis C patients }(\mathrm{n}=9) \\
\text { (Guanidinium extract) } \\
\text { (Proteinase K extract) }\end{array}$ & $8+/ 1-$ & $6+/ 2-$ \\
\hline
\end{tabular}

Proportion of viraemic anti-hepatitis C virus antibody positive individuals in different groups (tabs. 5 and 6)

Anti-hepatitis $\mathrm{C}$ virus antibody-positive sera from apparently healthy blood donors, from patients with hepatopathies and from haemophiliacs who had re-

Tab. 5. Proportion of hepatitis $\mathrm{C}$ virus carriers in different groups of anti-hepatitis $\mathrm{C}$ virus antibody positive individuals.

RNA was extracted with guanidinium salt solution cDNA was made with Moloney murine leukaemia virus reverse transcriptase and amplified with nested primers NCR 1 - NCR 4.

\begin{tabular}{lll}
\hline Group & Number & $\begin{array}{l}\text { Number of } \\
\text { hepatitis C } \\
\text { virus carriers }\end{array}$ \\
\hline $\begin{array}{l}\text { Blood donors } \\
\begin{array}{l}\text { Hepatitis C } \\
\text { patients }\end{array}\end{array}$ & 36 & 4 \\
\begin{tabular}{l} 
Haemophiliacs \\
\hline
\end{tabular} & 19 & 27 \\
\hline
\end{tabular}

ceived multiple doses of human plasma products before the introduction of virus inactivation procedures, were assayed by the polymerase chain reaction, following RNA extraction with guanidinium salt solution and reverse transcription with Moloney murine leukaemia virus reverse transcriptase. Hepatitis $C$ virus RNA was detected in $90 \%$ of the haemophiliacs (17 of 19$)$, and in $90 \%$ of the patients with clinically manifest "hepatitis non-A, non-B" (27 of 30), but only in $11 \%$ of apparently healthy blood donors with anti-hepatitis $C$ virus antibodies and normal serum alanine aminotransferase (4 of 36$)$.

\section{Examination of sera with elevated alanine aminotransferase catalytic concentrations}

Four hundred and fifty anti-hepatitis $C$ virus antibody-negative sera from blood donors with elevated serum alanine aminotransferase $(>25 \mathrm{U} / \mathrm{l})$ were extracted with guanidinium salt solution. The RNA extracts were reverse transcribed with Moloney mu-

Tab. 6. Detection of hepatitis C virus RNA in sera from haemophiliacs.

Antibodies were detected with 2nd generation enzyme anti-hepatitis $C$ immunoassay (Abbott, Wiesbaden). cDNA was prepared with Moloney murine leukaemia virus reverse transcriptase and amplified with nested primers NCR 1-NCR 4.

\begin{tabular}{llll}
\hline $\begin{array}{l}\text { Number of } \\
\text { patients }\end{array}$ & Clotting factor therapy & $\begin{array}{l}\text { Anti-hepatitis C } \\
\text { serostatus }\end{array}$ & $\begin{array}{l}\text { Hepatitis C virus } \\
\text { RNA detected in serum }\end{array}$ \\
\hline 3 & $\begin{array}{l}\text { Exclusively with virus } \\
\text { inactivated preparations } \\
\text { Therapy with plasma } \\
\text { preparations prior to } \\
\text { introduction of virus } \\
\text { inactivation procedures } \\
\text { Therapy with plasma } \\
\text { preparations prior to } \\
\text { introduction of virus } \\
\text { inactivation procedures }\end{array}$ & positive & yes \\
\hline
\end{tabular}


rine leukaemia virus reverse transcriptase, and nested polymerase chain reaction was performed with oligonucleotide primers NCR 1-NCR 4. No amplificates were observed.

\section{Ultracentrifugation of viraemic samples}

Virtually all virus particles were sedimented from very diluted serum samples by ultracentrifugation. RNA was extracted from three $200 \mu \mathrm{l}$ serum samples and in parallel from the pellets obtained after ultracentrifugation of such $200 \mu$ samples diluted in $35 \mathrm{ml}$ phosphate buffered saline solution. Both types of RNA extracts had the same virus RNA titre (detection limit $10^{3}$-fold dilution), indicating that all the RNA contained in a $200 \mu$ l serum sample could be recovered after ca. 160 -fold dilution and subsequent ultracentrifugation.

\section{Sequence determination of amplificates}

Four amplificates from nested polymerase chain reaction with primers NCR $1-\mathrm{NCR} 4$ from the 5'terminal non-coding region, spanning the sequence from nucleotide 10 to 288 , were sequenced. Nucleotide exchanges, as compared with the hepatitis $C$ virus $5^{\prime}$ terminal nucleotide sequence as published by $\mathrm{OKa}$ moto (21), occurred at three positions (tab. 7).

Tab. 7. Nucleotide sequence deviations of hepatitis $C$ virus cDNA amplificates from the $5^{\prime}$-terminal sequence as published by Okamoto (21)

\begin{tabular}{|c|c|c|c|}
\hline \multirow{2}{*}{$\begin{array}{l}\text { Amplificate } \\
\text { No. } \\
1\end{array}$} & \multicolumn{3}{|c|}{$\begin{array}{l}\text { Nucleotide exchange, position and type of } \\
\text { nucleotide }\end{array}$} \\
\hline & $187 \mathrm{~A}$ to $\mathrm{T}$, & $217 \mathrm{C}$ to $\mathrm{T}$, & $287 \mathrm{~A}$ to $\mathrm{G}$ \\
\hline 2 & $187 \mathrm{~A}$ to $\mathrm{C}$ & $217 \mathrm{C}$ to $\mathrm{T}$, & \\
\hline 3 & & $217 \mathrm{C}$ to $\mathrm{T}$, & \\
\hline 4 & $187 \mathrm{~A}$ to $\mathrm{T}$, & $217 \mathrm{C}$ to $\mathrm{T}$, & $287 \mathrm{~A}$ to $\mathrm{G}$ \\
\hline
\end{tabular}

\section{Discussion}

The combination of RNA extraction, reverse transcription and subsequent polymerase chain reaction is presently the only sensitive method available for hepatitis $C$ virus detection that permits the prediction of infectivity of patients and blood donors. We were able to demonstrate that stepwise optimization of this method can eliminate many false negative results.

Guanidinium salt solution was superior to other RNA extraction methods. Reverse transcription and subsequent cDNA amplification with nested oligonucleotide primers targeted to the 5 -terminal non-coding region of the hepatitis $\mathrm{C}$ virus genome detected the virus more often than with other primers $(21,22)$ (tab. 2 ). These results suggest that some recently published data on the prevalence of hepatitis $\mathrm{C}$ virus in antihepatitis $\mathrm{C}$ virus antibody positive patients and haemophiliacs may harbour some false negatives, since they were obtained using sub-optimal RNA extraction methods and primers $(12,16,20)$. In order to accumulate comparable data from different laboratories about hepatitis $\mathrm{C}$ virus prevalence in large numbers of samples, evaluation and standardization of the RNA detection procedures is required, including especially RNA extraction, reverse transcription, selection of oligonucleotide primers, and thermocycle conditions.

Hepatitis $\mathrm{C}$ virus particles may be recovered even from very dilute solutions by ultracentrifugation. Although this concentration step is not required when hepatitis C virus RNA is to be detected in single serum samples, ultracentrifugation may be very useful in the screening of large numbers of serum samples for hepatitis $C$ virus. All virus particles contributed to a serum pool by a single serum sample will be recovered from the pellet after ultracentrifugation, in spite of the dilution effect caused by the pooling. This approach is especially efficient when only very few of the screened samples contain the hepatitis $C$ virus, as should be the case with preselected anti-hepatitis C virus antibody-negative blood donors. Such a screening can close the diagnostic window between hepatitis $\mathrm{C}$ virus infection and anti-hepatitis $\mathrm{C}$ seroconversion. Hepatitis $\mathrm{C}$ virus detection in all blood donations, combined with antibody screening, should be made mandatory with the aim of preventing transfusionrelated hepatitis $C$ virus transmissions.

We found markedly different proportions of virus carriers in three groups of anti-hepatitis $\mathrm{C}$ virus antibody positive people, namely hepatitis $\mathrm{C}$ patients, haemophiliacs and blood donors (tab. 5).

The rate of $90 \%$ hepatitis $C$ virus carriers among "hepatitis non-A, non-B" patients both with acute and chronic disease reflects the strong tendency of the hepatitis $\mathrm{C}$ infection to become chronic. With this in mind, we should undertake every possible effort to prevent the iatrogenic transmission of this virus infection, e.g. via blood transfusions.

We examined sera from 19 haemophiliacs who had received multiple doses of human plasma products before the introduction of virus inactivation procedures. All of them had anti-hepatitis $\mathrm{C}$ virus antibodies, and 17 of them carried the hepatitis $\mathrm{C}$ virus. Plasma derived clotting factor is the most likely source of their hepatitis $\mathrm{C}$ infections $(38,39)$. Another 3 
haemophiliacs in our study had been treated exclusively with virus-inactivated plasma products. They had no anti-hepatitis $C$ virus antibodies and were not viraemic (tabs. 5 and 6). These findings reflect both the usefulness of virus inactivation procedures and the fact that viraemic plasma donors have contributed and probably continue to contribute to human plasma pools.

Among 36 anti-hepatitis $\mathrm{C}$ virus antibody positive blood donors, we found only $11 \%$ (4 of 36 ) viraemic individuals (tab. 5). This observation suggests that their apparent well-being correlated with periods of aviraemia. However, these blood donors were preselected, because we require that our blood donors be anti-HBc negative.

Anti-HBc antibodies are regarded as a marker not only for hepatitis B, but rather as marker of increased susceptibility to other infections which may be transmitted by blood. There are reports in the literature of the detection of anti-hepatitis $\mathrm{C}$ virus antibodies in archivated sera from blood donors involved in transfusion-related "heaptitis non- $A$, non- $B$ " transmission $(40-42)$. These donors had not been prescreened for anti-HBc antibodies and must be regarded as chronic hepatitis $\mathrm{C}$ virus carriers from their history. Two other reports $(43,44)$ give data about anti-hepatitis $C$ virus antibody status and hepatitis $C$ virus detection in the sera of randomly selected blood donors in London and in Australia who had not been prescreened for anti-HBc antibodies. The proportion of hepatitis $C$ virus carriers among the anti-hepatitis $\mathrm{C}$ virus antibody positive blood donors in these studies was higher than in our study. In a study on blood donors with elevated serum alanine aminotransferase
(13), ca. $8 \%$ of the donors were found to be hepatitis $\mathrm{C}$ virus carriers and $4 \%$ were anti-HBc antibodypositive. Anti-HBc screening prior to the admission of blood donors obviously helps to identify some hepatitis $\mathrm{C}$ virus carriers.

Elevated serum alanine aminotransferase in donated blood has previously served as a surrogate marker to hepatitis non-A, non-B in Germany. Even after introduction of the anti-hepatitis $C$ virus antibody screening, serum alanine aminotransferase determination was continued in order to detect hepatitis $\mathrm{C}$ virus infections during the interval before seroconversion. We did not detect hepatitis $C$ virus RNA in 450 blood donor sera with elevated alanine aminotransferase (above $25 \mathrm{U} / \mathrm{l}$ ). Moreover, all the viraemic blood donors in our study did not have elevated serum alanine aminotransferase, nor had they ever had elevated serum alanine aminotransferase during their history as blood donors. If serum alanine aminotransferase activity in blood donors cannot detect hepatitis $\mathrm{C}$ infections, what is its purpose now?

The usefulness of the polymerase chain reaction, combined with efficient nucleic acid extraction, for the detection of hepatitis $C$ virus has been demonstrated. The method can be adapted to screening procedures and will soon find many routine applications both in transfusion medicine and in general infectiology.

\section{Acknowledgement}

We thank Prof. Dr. E. Lechler, Klinik I für Innere Medizin der Universität zu Köln, for provision of 22 sera from haemophiliacs, and Dr. N. Petersen, Institut für Blutspendewesen, Städtische Kliniken Dortmund, for provision of 320 blood donor sera with elevated alanine aminotransferase activities.

\section{References}

1. Choo, Q. L., Kuo, G., Weiner, A. J., Overby, L. R., Bradley, D. W. \& Houghton, M. (1989) Isolation of a cDNA Clone Derived from a Blood-borne Non-A, Non-B Viral Hepatitis Genome. Science 244, 359-362.

2. Choo, Q.-L., Weiner, A. J., Overby, L. R., Kuo, G. \& Houghton, M. (1990) Hepatitis C virus: The major causative agent for viral non-A, non-B hepatitis. Brit. Med. Bull. $46,423-441$.

3. Houghton, M., Weiner, A., Han, J., Kuo, G. \& Choo, Q.L. (1991) Molecular Biology of the Hepatitis C Viruses: Implications for Diagnosis, Development and Control of Viral Disease. Hepatology 14, $381-388$.

4. Kuo, G., Alter, H. J., Gitnick, G. L., Redeker, A. G., Purcell, R. H., Miyamura, T., Dienstag, J. L., Alter, M. J., Stevens, C. E., Tegtmeier, G. E., Bonino, F., Colombo, M., Lee, W.-S., Kuo, C., Berger, K., Shuster, J. R., Overby, L. R., Bradley, D. W. \& Houghton, M. (1989) An Assay for Circulating Antibodies to a Major Etiologic Virus of $\mathrm{Hu}-$ man Non-A, Non-B Hepatitis. Science 244, 362-364.

5. Miller, R. H. \& Purcell, R. H. (1990) Hepatitis C virus shares amino acid sequence similarity with pestiviruses and

flaviviruses as well as members of two plant virus supergroups. Proc. Natl. Acad. Sci. USA 87, 2057-2061.

6. Alter, J. J., Hadler, S. C., Judson, F. N., Mares, A., Alexander, W. J., Ya Hu, P., Miller, J. K., Moyer, L. A., Fields, H. A., Bradley, D. W. \& Margolis, H. S. (1990) Risk Factors for acute Non-A, Non-B Hepatitis in the United States and Association with Hepatitis C Virus Infection. J. Am. Med. Ass. 264, 2231-2235.

7. Feinstone, S. M., Kapikian, A. Z., Purcell, R. H., Alter, H. J. \& Holland, P. V. (1975) Transfusion-associated hepatitis not due to hepatitis type A or B. N. Engl. J. Med. 292, 767-770.

8. UK Patent Application GB 2212511 A, 18. 11. 1988, and European Patent Application 88310922.5, 18. 11. 1988, Chiron Corporation, Emeryville, California.

9. Alter, H. J., Purcell, R. H., Shih, J. W., Melpolder, J. C., Houghton, M., Choo, Q.-L. \& Kuo, G. (1989) Detection of antibody to hepatitis $\mathrm{C}$ virus in prospectively followed transfusion recipients with acute and chronic non-A, nonB hepatitis. N. Engl. J. Med. 321, 1494-1500. 
10. Miyamura, R., Saito, I., Katayama, T., Kikuchi, S., Tateda, A., Houghton, M. \& Choo, Q.-L. (1990) Detection of antibody against antigen expressed by molecularly cloned hepatitis $\mathrm{C}$ virus $\mathrm{CDNA}$ : application to diagnosis and blood screening for posttransfusion hepatitis. Proc. Natl. Acad. Sci. USA 87, 983-987.

11. Prohaska, W., Schroeter, E., Kaars-Wiele, P. \& Kleesiek, K. (1992) Enzyme Immunoassays for Anti-Hepatitis C Virus Antibodies, Improved Specificity and Analytical Sensitivity of Three Different Recombinant Viral Proteins in Second Generation Tests. Eur. J. Clin. Chem. Clin. Biochem. 30, 397-404.

12. Simmonds, P., Zhang, L. Q., Watson, H. G., Rebus, S., Ferguson, E. D., Balfe, P., Leadbetter, G. H., Yap, P. L., Peutherer, J. F. \& Ludlam, C. (1990) Hepatitis C quantification and sequencing in blood products, haemophiliacs, and drug users. Lancet 336, 1469-1472.

13. Ulrich, P. P., Romeo, J. M., Lane, P. K., Kelly, I., Daniel, L. J. \& Vyas, G. N. (1990) Detection, Semiquantitation, and Genetic Variation in Hepatitis C Virus Sequences Amplified from the Plasma of Blood Donors with Elevated Alanine Aminotransferase. J. Clin. Invest. 86, 1609-1614.

14. Scotto, J., Hadchouel, M., Hery, C., Yvart, J., Tiollais, P. \& Brechot, C. (1983) Detection of hepatitis B virus DNA in serum by a simple spot hybridization technique: comparison with results for other virus markers. Hepatology 3 , 279-284.

15. Arnold, L. J., Hammond, P. W., Wiese, W. A. \& Nelson, N. C. (1989) Assay formats involving acridinium-esterlabeled DNA probes. Clin. Chem. 35, 1588-1594.

16. Weiner, A. J., Kuo, G., Bradley, D. W., Bonino, F., Saracco, G., Lee, C., Rosenblatt, J., Choo, Q.-L. \& Houghton, M. (1990) Detection of hepatitis $C$ viral sequences in non-A, non-B hepatitis. Lancet 335, $1-3$.

17. Garson, J. A., Ring, C., Tuke, P. \& Tedder, R. S. (1990) Enhanced detection by PCR of hepatitis C virus RNA. Lancet 333, 878-879.

18. Gärson, J. A., Tuke, P. W., Makris, M., Briggs, M., Machin, S. J., Preston, F. E. \& Tedder, R. S. (1990) Demonstration of viraemia patterns in haemophiliacs treated with hepatitis-C-virus-contaminated factor VIII concentrates. Lancet 336, 1022-1025.

19. Garson, J. A., Tedder, R. S., Briggs, M., Tuke, P., Glazebrook, J. A., Trute, A., Parker, D., Barbara, J. A. J., Contreras, M. \& Aloysius, S. (1990) Detection of hepatitis $\mathrm{C}$ viral sequences in blood donations by "nested" polymerase chain reaction and prediction of infectivity. Lancet 335, 1419-1422.

20. Kato, N., Yokosuka, O., Hosoda, K. \& Ohto, M. (1990) Detection of Hepatitis C Virus Ribonucleic Acid in the Serum by Amplification with Polymerase Chain Reaction. J. Clin. Invest. 86, 1764-1767.

21. Okamoto, H., Okada, S., Sugiyama, Y., Tanaka, T., Sugai, Y., Akahane, Y., Machida, A., Mishiro, S., Yoshizawa, H., Miyakawa, Y. \& Mayumi, M. (1990) Detection of Hepatitis $C$ Virus RNA by a Two-Stage Polymerase Chain Reaction with Two Pairs of Primers Deduced from the $5^{\prime}$-Noncoding Region. Japan. J. Exp. Med. 60, 215-222.

22. Christiano, K., Di Bisceglie, A. M., Hoofnagle, J. M. \& Feinstone, S. M. (1991) Hepatitis C Viral RNA in Serum of Patients with Chronic Non-A, Non-B Hepatitis: Detection by the Polymerase Chain Reaction Using Multiple Primer Sets. Hepatology 14, 51-55.

23. Busch, M. P. \& Wilber, J. C. (1992) Hepatitis C virus replication. N. Engl. J. Med. 326, 64-65.

24. Kato, N., Hijikata, M., Ootsuyama, Y., Nkagawa, M., Ohkoshi, S. \& Shimotono, K. (1990) Sequence Diversity of Hepatitis C Viral Genomes. Mol. Biol. Med. 7, 495-501.

25. Kato, N., Hijikata, M., Ootsuyama, Y., Nakagawa, M., Ohkoshi, S., Sugimura, T. \& Shimotohno, K. (1990) Molecular cloning of the human hepatitis $C$ virus genome from Japanese patients with non-A, non-B hepatitis. Proc. Natl. Acad. Sci. USA 87, 9524-9528.
26. Chen, P.-J., Lin, M.-H., Tu, S.-J. \& Chen, D.-S. (1991) Isolation of Complementary DNA Fragment of Hepatitits C Virus in Taiwan Revealed Significant Sequence Variations Compared with Other Isolates. Hepatology 14, 73-78.

27. Hijikata, M., Kato, N., Ootsuyama, Y., Nakagawa, M., Ohkoshi, S. \& Shimothono, K. (1991) Hypervariable Regions in the Putative Glycoprotein of Hepatitis C Virus. Biochem. Biophys. Res. Comm. 175, 220-228.

28. Weiner, A. J., Brauer, M. J., Rosenblatt, J., Richman, K. H., Tund, J., Crawford, K., Bonino, F., Saracco, G., Choo, Q.-L., Houghton, M. \& Han, J. H. (1991) Variable and Hypervariable Domains Are Found in the Regions of HCV Corresponding to the Flavivirus Envelope and NS1 Proteins and the Pestivirus Envelope Glycoproteins. Virology $180,842-848$

29. Choo, Q.-L., Richman, K. H., Han, J. H., Berger, K., Lee, C., Dong, C., Gallegos, C., Coit, D., Medina-Selby, A., Barr, P. J., Weiner, A. J., Bradley, D. W., Kuo, G. \& Houghton, M. (1991) Genetic organization and diversity of the hepatitis C virus. Proc. Natl. Acad. Sci. USA 88, $2451-2455$.

30. Fuchs, K., Moth, M., Schreier, E., Zachoval, R., Deinhardt, F. \& Roggendorf, M. (1991) Characterization of nucleotide sequences from European hepatitis $C$ virus isolates. Gene 103, 163-169.

31. Han, J. H., Shymala, V., Richman, K. H., Brauer, M. J., Irvine, B., Urdea, M. S., Tekamp-Olson, P., Kuo, G., Choo, Q.-L. \& Houghton, M. (1991) Characterization of the terminal regions of hepatitis C viral RNA: Indentification of conserved sequences in the $5^{\prime}$ untranslated region and poly(A) tails at the $3^{\prime}$ end. Proc. Natl. Acad. Sci. USA 88, $1711-1715$.

32. Ogata, N., Alter, H. J., Miller, R. H. \& Purcell, R. H. (1991) Nucleotide sequence and mutation rate of the $\mathrm{H}$ strain of hepatitis C virus. Proc. Natl. Acad. Sci. USA 88, 3392-3396.

33. Chomczynski, P. \& Sacchi, N. (1987) Single-step method of RNA isolation by acid guanidinium thiocyanate-phenolchloroform extraction. Anal. Biochem. 162, 156-159.

34. Sambrook, J., Fritsch, E. F. \& Maniatis, T. (1989) Molecular Cloning vol. 2, 2nd edition, 11.23, Cold Spring Harbor Laboratory Press, Cold Spring Harbor.

35. Kwok, S. \& Higuchi, R. (1989) Avoiding false positives with PCR. Nature 339, 237-238, erratum published in Nature 339, 490.

36. Sambrook, J., Fritsch, E. F. \& Maniatis, T. (1989) Molecular Cloning vol. 2, 2nd edition, 13.42, Cold Spring Harbor Laboratory Press, Cold Spring Harbor.

37. Bergmeyer, H. U. (1972) Empfehlungen der Deutschen Gesellschaft für Klinische Chemie. J. Clin. Chem. Clin. Biochem. 10, $281-291$.

38. Fletcher, M. L., Trowell, J. M., Pavier, K. \& Rizza, C. R. (1983) Non-A, Non-B hepatitis after transfusion of factor VIII in infrequently treated patients. Br. Med. J. 287, $1754-1757$.

39. Garson, J. A., Preston, F. E., Makris, M., Tuke, P., Ring, C., Machin, S. J. \& Tedder, R. S. (1990) Detection by PCR of hepatitis $\mathrm{C}$ virus in factor VIII concentrates. Lancet 335, 1473.

40. Shibata, M., Morishima, T., Kudo, T., Maki, T., Maki, S. \& Nagai, Y. (1991) Serum Hepatitis C Virus Sequences in Postransfusion Non-A, Non-B Hepatitis. Blood 77, 11571160.

41. van der Poel, C. L., Lilie, P. N., Choo, Q.-L., Reesink, H. W., Leentvaar-Kuypers, A., Kuo, G. \& Houghton, M. (1989) Anti-hepatitis C antibodies and Non-A, Non-B posttransfusion hepatitis in the Netherlands. Lancet II, 297298.

42. van der Poel, C. L., Reesink, H. W., Schaasberg, W., Leentvaar-Kuypers, A., Bahler, E., Exl-Oehlers, P. J. \& Lilie, P. N. (1991) Infectivity of blood seropositive for hepatitis C virus antibodies. Lancet $335,558-560$. 
43. Weiner, A. J., Truett, M. A., Rosenblatt, J., Han, J., Quan, S., Polito, A. J., Kuo, G., Choo, Q.-L., Houghton, M., Aguis, C., Page, E. \& Nelles, M. (1990) HCV testing in low risk population. Lancet 336, 695 .

44. Allain, J.-P., Coghlan, P. J., Kenrick, K. G., Whitson, K., Keller, A., Cooper, G. J., Vallari, D. S., Delaney, S. R. \& Kuhns, M. C. (1991) Prediction of Hepatitis C Virus Infectivity in Seropositive Australian Blood Donors by Supplemental Immunoassays and Detection of Viral RNA. Blood 78, 2462-2468.
45. Takamizawa, A., Mori, C., Fuke, I., Manabe, S., Murakami, S., Fujita, J., Onishi, E., Andoh, T., Yoshida, I. \& Okayama, H. (1991) Structure and Organization of the Hepatitis C Virus Genome Isolated from Human Carriers. J. Virol. 65, 1105-1113.

Dr. rer. nat. Dr. med. Carsten Wolff

Prof. Dr. med. Knut Kleesiek

Herzzentrum Nordrhein-Westfalen

Universitätsklinik der Ruhr-Universität Bochum Institut für Laboratoriums-

und Transfusionsmedizin

Georgstraße 11

W-4970 Bad Oeynhausen

Bundesrepublik Deutschland 
